\title{
Unraveling the taxonomic identity of Cocos nucifera f. palmyrensis (Arecaceae: Cocoseae)
}

\author{
Hugh C. Harries ${ }^{\dagger}$, Lia Pignotti \& Riccardo M. Baldini
}

\begin{abstract}
HARRIES, H.C.†, L. PIGNOTTI \& R.M. BALDINI (2020). Unraveling the taxonomic identity of Cocos nucifera f. palmyrensis (Arecaceae: Cocoseae). Candollea 75: 25-30. In English, English abstract. DOI: http://dx.doi.org/10.15553/c2020v751a2

The main traits of the rich equatorial vegetation covering the remote coral atoll Palmyra in North Pacific Ocean, where groves of Cocos nucifera L. (Arecaceae) currently dominate on other formations, are here summoned. Way and timing of human activities in historical and more recent times, which possibly altered the original vegetation, are also briefly reviewed. The unusually large size of Palmyra coconut fruits had astonished the American botanist Joseph Francis Rock (1884-1962) who sent four fruits to the renowned Florentine palm specialist Odoardo Beccari (1843-1920). Beccari described the material and validly published it in 1916 as Cocos nucifera f.palmyrensis Becc. Part of the original material was retrieved at FI. One of the two coconut fruits still kept at FI is here designated as lectotype of the Beccari name, which is here elevated to the rank of variety, reflecting better than form current concepts for isolated island populations. Palmyra Atoll with its coconuts played a part in the age-old dispute on the geographical origin of Cocos nucifera. This taxon was cited by Beccari and by Emilio Chiovenda (1871-1941) as a support to their hypotheses of an Asian origin of the species. The significance of these dated interpretations in the light of currently available information is here briefly discussed.
\end{abstract}

\section{Keywords}

ARECACEAE - Arecoideae - Cocoseae - Cocos nucifera f. palmyrensis - Pacific Ocean - Palmyra Atoll - Typification

Address of the authors:

LP, RMB: Dipartimento di Biologia and Centro Studi Erbario Tropicale (Herbarium FT),

Università di Firenze, Via G. La Pira 4, 50121, Firenze, Italy. E-mail: rbaldo@unifi.it

Submitted on October 16, 2019. Accepted on February 4, 2020.

First published online on March 24, 2020. 


\section{Introduction}

Palmyra atoll is a United States possession in the Central Pacific Ocean, at the north end of the Line Islands (Fig. 1). With its highly humid (> 90 percent), rainy (nearly $4500 \mathrm{~mm}$ rain per year) and warm $\left(24-27^{\circ} \mathrm{C}\right.$ ) aseasonal equatorial climate (SADLER, 1959), Palmyra is heavily vegetated on most of its islets (Hathaway et al., 2011). The atoll was probably known to inhabitants of Micronesia and Polynesia, who explored it but never settled down there (Hathaway et al., 2011). Although previously sighted by the American sea captain Edmond Fanning in 1798, it was officially discovered in 1802 by Captain Sawle - also an American - who named it after his vessel Palmyra (Rock, 1916; Hathaway et al., 2011).

According to relatively recent vegetation mapping (Wegmann, 2005) about 43\% of Atoll supports coconut palm forest; about $29.5 \%$ harbours coastal strand forest of dominant beach naupaka (Scaevola taccada (Gaertn.) Roxb., Goodeniaceae) and tree heliotrope (Tournefortia argentea L. f., Boraginaceae); about $12 \%$ harbours some of the best preserved stands of the protected Pisonia grandis R. Br. (Nyctaginaceae) forest, typical of coral islands of the Pacific and Indian Oceans and now regarded as seriously declining in connection with human activities (WALKER, 1991). Small groves of the native Pandanus tectorius Parkinson (Pandanaceae) are scattered in 20 of the islets, as well as small grassland patches, represented by the native Lepturus repens (G. Forst.) R. Br. with the endemic var. palmyrensis F. Br. (Poaceae) (Hathaway et al., 2011).

According to Herbst (1992), prior to human visitation Pisonia grandis forest was probably the dominant vegetation type, fringed by coastal strand forest of pioneer beach naupaka on lagoon borders and tree heliotrope on the ocean edges. He acknowledges the possibility that Polynesians would clear large areas of $P$. grandis forest for firewood and in order to favour coconut palm stands. Although coconut palm is considered by many an early introduction of Polynesian explorers of Palmyra, it is easily admissible that it could have arrived by its own dispersal means and that it would have been subsequently favoured by Polynesians in the way described. Further expansion of coconut palm then took place prior, during and after US military occupation of the Atoll up to at least 1957, when attempts to establish lucrative coconut plantations were made (Dawson, 1959). Cocos nucifera has, moreover, shown invasive behaviour at Palmyra, increasing from less than one million trees in 1886 to about two millions, and becoming the dominant forest type (Rock, 1916; Hat HaWAY et al., 2011): it quickly colonizes clearings opened in other forest types (Herbst, 1992; Freeman, 2006a), is more effective than other native species in nutrient uptake, and its falling nuts and fronds damage the surrounding vegetation facilitating its own expansion (Hathaway \& al., 2011). Possible arguments in favour of the non-native nature of coconut palm at Palmyra are that it is used by few birds for roosting, and by

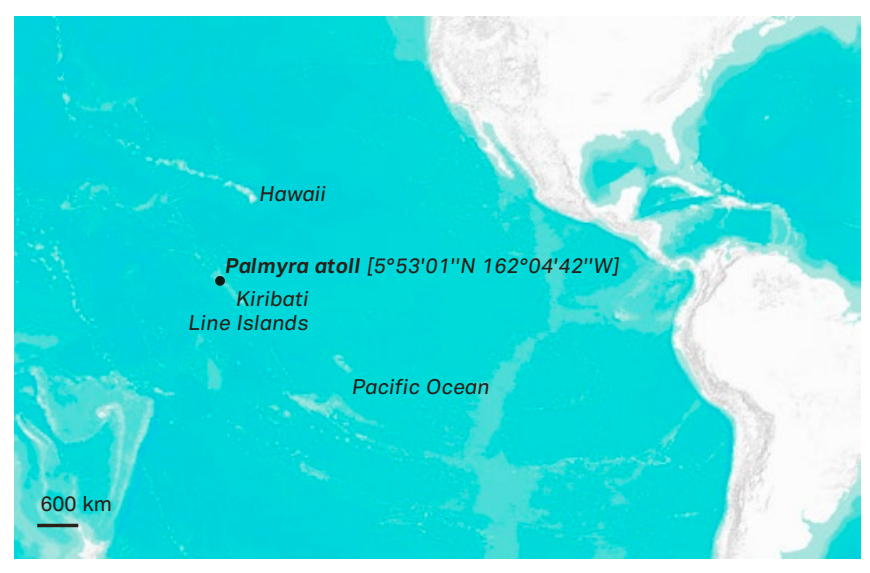

Fig. 1. - Location of Palmyra Atoll in North Pacific Ocean (circle) south of Hawaii.

even fewer for nesting (Young et al., 2010), while it offers food and shelter to the non-native pest black rat (Rattus rattus). On the other hand, coconuts are a food source to coconut crabs (Birgus latro), which are generally considered native to Palmyra (Hat haway et al., 2011).

The American botanist Joseph Francis Rock (1884-1962) carried out at Palmyra in July 12-28,1913 "a more or less thorough investigation during a stay of sixteen days on the island" and subsequently published the first Flora, including 15 species of vascular plants (Rock, 1916). Earlier, STreEts (1877) had already collected plants there in 1873 within the framework of an investigation devoted to the Fanning group of islands. Further collections were made in 1958 by E. Yale Dawson, who investigated the effects of the heavily impacting human activities begun in wartime - and just then coming to an end - on the vegetation (Dawson, 1959). Herbst $(1988,1992)$ visited Palmyra Atoll in 1987 and 1992, and produced a new vascular flora, also describing the plant associations observed on the different islets. Plant list and vegetation data were further updated by FreEMAN $(2006 a, 2006 \mathrm{~b})$ who reported 78 vascular plant species, of which only 25 he considered native, the remaining 53 intentional and unintentional introductions.

Rоск (1916) carried out the investigation of the flora of Palmyra and sent material to the respective specialists including Pandanaceae to Ugolino Martelli (1860-1934) and Arecaceae to Odoardo Beccari (1843-1920) in Florence. Martelli (1916) described two new taxa on Rock's material: Pandanus rockii Martelli and P. pulposus var. cooperi Martelli, which are now considered synonyms of widespread coastal P. tectorius Parkinson (Pandanaceae Project, 2019). Original material can be found on the MSNFI (2019) website. With regards to Arecaceae Rоск (1916: 28) wrote: "The nuts of the Palmyra coconut are the finest and the biggest the writer has ever seen, which testimony is also given by the eminent authority, Dr. O. Beccari of Florence, Italy". 


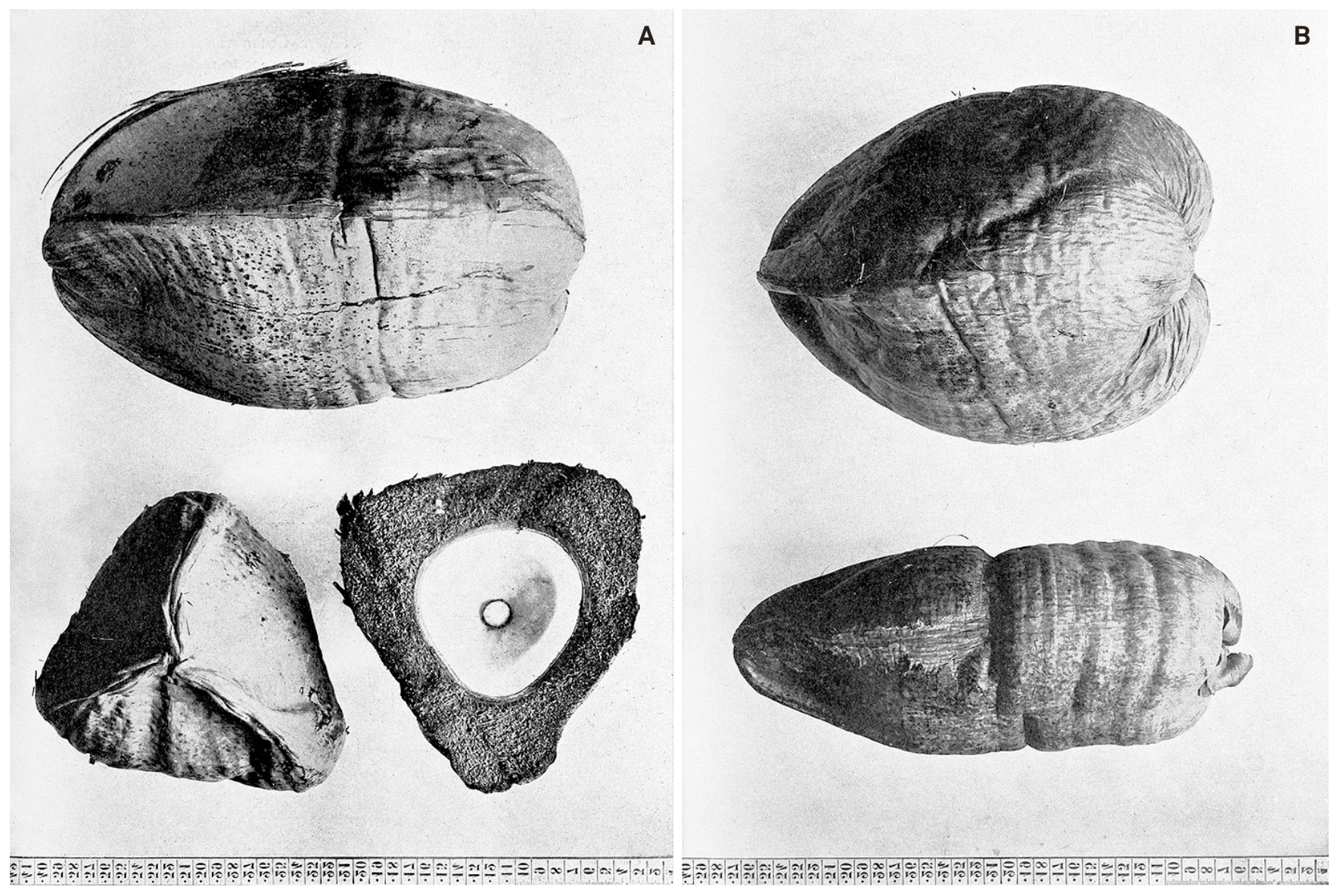

Fig. 2. - Original material of Cocos nucifera var. palmyrensis (Beccari) Pignotti \& Baldini. A. top: lectotype; bottom: upper view and cross sectioned by Beccari of a fruit now missing at Fl; B. top: syntype; bottom: lateral view of a slender coconut, now missing at Fl. [A top: FI018792; B top: FI018793] [Reproduced from the Bull. Coll. Hawaii Publ. 4: tab. XVII, XVIII]

Thanks to the retrieval of part of the original material in FI, Beccari's name C. nucifera f. palmyrensis is here lecto and raised to variety. A brief illustration of the role assumed by Palmyra coconut in the historical debate on the geographical origin of Cocos nucifera is also given.

\section{On the original description and characteristics of the Palmyra coconut}

Beccari (1916) described the Palmyra coconut in detail based on four fruits that he received from Rock. He described it as a new forma, Cocos nucifera $\mathrm{f}$. palmyrensis Beccari based on its large size, length, and distinctly trigonal shape, especially at apex. The four fruits received by Beccari differed greatly from each other in size and shape and were described in detail (see BECCARI, 1916: 44-48). Beccari was especially impressed by the length of the largest of the four fruits $(36 \mathrm{~cm})$, which he believed not to have seen the like from any other collection except two fruits he was aware of deposited at $\mathrm{K}$, originating from South-East Asia (Amman and Strait Settlements). The fruit originating from the Strait Settlements (former British colony on the Strait of Malacca) had an exceptionally large diameter of $35.5 \mathrm{~cm}$, which Beccari supposedly attributed to the development of three instead of only one ovule (BECCARI, 1916). Beccari made a cross section of the third Palmyra fruit and noted that the solid endosperm of the seed (he used the term 'albumen', i.e., the white fleshy layer of the seed, from which copra is extracted) was unusually thick: $15 \mathrm{~mm}$, while 11-12 $\mathrm{mm}$ was normally considered by him as a very thick endosperm. Two plates were published in BECCARI (1916: tab. XVII, XVIII) and are reproduced in Fig. 2 for better explanation of its morphology. Finally, Beccari also made a buoyancy test with one fruit, and was surprised by its low specific weight, which made possible for it to float upon one flat side, having most of the surface above water, including the proximal germination pole, which appeared to be located in the lightest region and, as a consequence, the highest above water. 


\section{Typification}

Cocos nucifera var. palmyrensis (Beccari) Pignotti \& Baldini, stat. nov.

$\equiv$ Cocos nucifera f.palmyrensis Beccari in Rock, Bull. Coll. Hawaii Publ. 4: 44. 1916.

Lectotypus (designated here): Palmyra Island: "Palyra [sic!] Islands (Oceano Pacifico)", 1914, Rock s.n. (FI [FI018792]!). Syntypus: Palmy ra Islands: "Palmyra Islands", 1914, Rock s.n. (FI [FI018793]!).

Notes. - Only two fruits have been retrieved at FI. The largest one [FI018792] and the second largest [FI018793]. The cross-sectioned (Fig. 2A, bottom) and the fourth, slender one (Fig. 2B, bottom) are inexplicably missing. Somewhat blurred annotations in Beccari's handwriting are present on the smooth surface of the husk of each coconut fruit (Fig. 3). Probably written by fountain pen or indelible pencil, the two annotations had apparently been overlooked since 1937, when Beccari's Herbarium Palmarum was acquired by FI (CuccuinI \& NePi, 2006). [FI018792] bears "Palyra [sic!] Islands/ (Oceano Pacifico)/ Dal Sig. Rock 1914/ Collez. O. Beccari” (Fig. 3A) and - on the opposite side - "Palmyra Islands/ Dal Sig. Rock/ 1914", the latter also present on [FI018793] (Fig. 3B). The larger coconut, [FI018792], is here chosen as the lectotype of Cocos nucifera f.palmyrensis (Fig. 4).

\section{Palmyra's coconut and the dispute on the "cradle" of Cocos nucifera}

As observed by Harries \& Harries (2018) it was from Rock's report on Palmyra and how coconut palms thrive there, as well as from his own observations and experiences on these samples, that Beccari was encouraged to publish in 1917 his paper "Origin and dispersal of Cocos nucifera", in which he declared himself inclined to think that Cocos nucifera, a halophylous plant highly adapted to sea shore habitats and to dispersal by oceanic currents, had evolved in coral atoll ecosystems and was probably of Asiatic or Polynesian origin rather than American (Beccari, 1917). This was in open contrast with Cook's thesis of a South American, dry inland origin of Cocos nucifera, mainly based on the presence there of other native, cocosoid palms (Соок, 1901,1910) as also supported long before by Martius (1823-1850). On the other hand, a thoroughgoing review on the issue was published a few years later in Italian by the Italian botanist Emilio Chiovenda (1871-1941), who supported the hypothesis of an Asiatic origin of Cocos nucifera (precisely from regions now submerged in NW Indian Ocean). Chiovenda $(1921,1923)$ took into account the observations and buoyancy experiments made by Beccari on C. nucifera f. palmyrensis, and also supported the hypothesis of sea floating as the main dispersal way. He mentioned the observation made by BeCCARI (1916) on Palmyra's

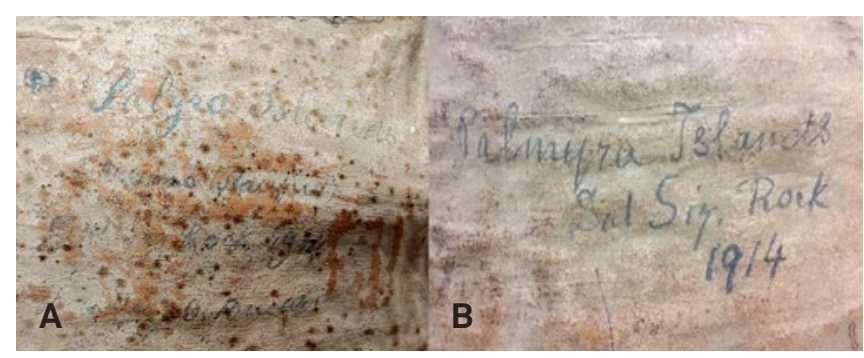

Fig. 3. - Close-up of the original note on original material of Cocos nucifera var. palmyrensis (Beccari) Pignotti \& Baldini. A. Lectotype; B. Syntype.

[A: FI018792; B: FI018793] [Photos: D. Nesti, L. Pignotti]

fruits that the spongy, permeable tissue at the germination pole constantly remains upon water thanks to its astonishing low specific weight, so preventing the embryo from hydration and to germinate while still afloat.

The large size of the fruits measured by BECCARI (1916) was also an argument of interest to Chiovenda $(1921,1923)$. Forms with large fruits prevail in the Pacific islands, while in the Indian Ocean fruits have as a rule a smaller size, supporting Chiovenda's hypothesis that the origin of Cocos nucifera from ancestral, small fruited forms should be found in ancient, now submerged land in NW Indian Ocean. The species would have thrived within the coral archipelagos of the Indian Ocean for a long time, until humans carried it to Sri Lanka and India, then to Malaysia. From there, it could have spread spontaneously to the Pacific atolls by ocean currents or, more probably, carried by eastward migrating inhabitants of Malaysia (Chiovenda, 1921, 1923).

\section{Epilogue}

The dispute on the geographical and ecological origin of Cocos nucifera and the meaning of its present distribution and variability went on well after Chiovenda's contribution in the early 1920s: the issue has actually remained controversial until present date. For a thorough review see Harries \& Harries (2018). Recent phylogenetical studies on the tribe Cocoseae (Dransfield et al., 2008; Baker \& Dransfield, 2016) - which includes, in addition to Cocos, a majority of 13 Neotropical genera, two Madagascan, one amphi-Atlantic (Elaeis Jacq.), one South-African (Jubaeopsis Becc.) - although still providing 'fluid' results, hint at a South American origin of Cocos nucifera (Meerow et al., 2009, 2015). Nonetheless, coconut palm evolution and dispersal through coral island systems (atoll ecosystem hypothesis) is well supported and it is noteworthy that the distance among shallow, warm ocean areas suitable for coral atoll formation must have been shorter when this evolution took place than today (BLAKEY, 2008; Harries \& Clement, 2014), accounting for a route running from South America, through a narrow Atlantic and an archipelago-like southern Europe eastwards to southern Asia 


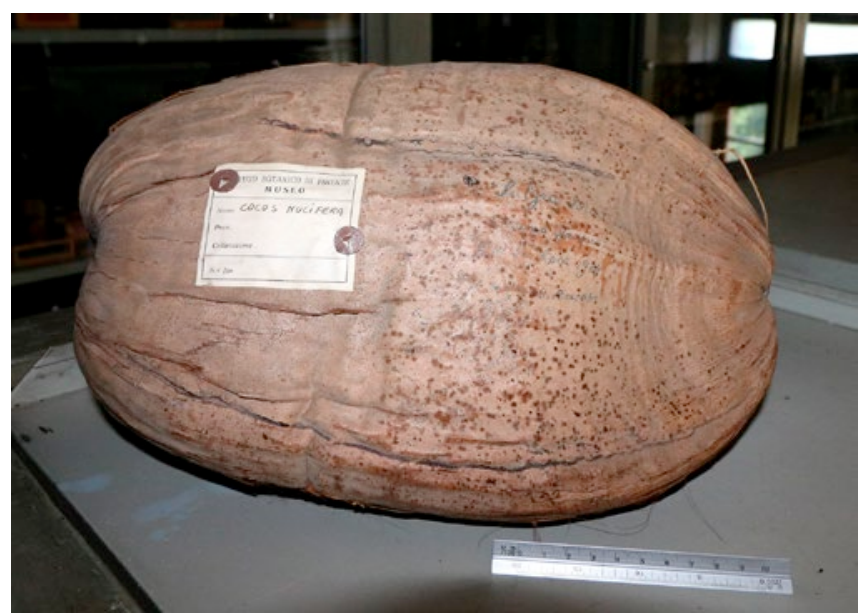

Fig. 4. - Lateral view of the lectotype of Cocos nucifera var. palmyrensis (Beccari) Pignotti \& Baldini. [FI018792] [Photo: L. Pignotti]

and India, which would explain the presence of Paleo-Eocene coconut-like fossils in Colombia (Gomez-Navarro et al., 2009) and India (ShukLA et al., 2012).

The view of most researchers who have dealt with the origin of the coconut palm - among them FosBERG (1960) and Purseglove $(1968,1972)$ - of all existing coconuts being exclusively a product of human selection from extinct or unknown small wild forms seems a prejudicial constriction not supported by facts (Harries, 1978). On this account, the noteworthy length, trigonal cross-section and thickness of the husk of C. nucifera var. palmyrensis arguably suggest that no selection was ever carried out on them by man. These characters were not indeed traditionally favoured by people interested in (and more or less consciously selecting) coconuts as a source of drinkable water (HARRIEs, 1978, 1979): elongated, triangular coconuts with thick husk contain less water (liquid endosperm) than spherical ones (Harries, 2012). But this syndrome of characters also affects the thickness of kernel and, as a consequence, selection for copra: coconuts with much water also have a thick kernel (solid endosperm), which develops at the expense of the husk and shell. That means that selection for drinkable water and for copra would widely coincide. In turn, a thin husk represents quicker germination, which was a character favoured by farmers; in contrast, thick-husked coconuts are recalcitrant and reach $90 \%$ germinability only after 60-220 days (Whit EHEAD, 1965). This is an advantage in the wild, favouring dissemination to new shore localities (Harries, 1981), but it is not needed or represents a hindrance in plantations.

In conclusion, the C. nucifera var. palmyrensis producing elongated, trigonous, thick-husked, slow-germinating coconuts might have been present before - and might have withstood - any possible introduction therein of selected spherical, thin-husked, quick-germinating seed-nuts (SAUER, 1967; Harries, 2012).

\section{Acknowledgements}

The first author Hugh C. Harries passed away on February $7^{\text {th }}$ 2019; to the skilful, passionate scientist the co-authors dedicate this contribution.

We heartily thank Jane Harries for her review of the English, and are grateful to Fred Stauffer and Martin Callmander for their critical review and crucial suggestions on the manuscript. Acknowledgements are due to the Keeper, Chiara Nepi, and technicians of FI, for freely allowing us to look for the 'right coconuts' in the dedicated cupboard of the Florentine carpological collection.

\section{References}

Baker, W.J. \& J. Dransfield (2016). Beyond Genera Plantarum: progress and prospects in palm systematics. Bot. J. Linn. Soc. 182: 207-233.

Beccari, O. (1916). Arecaceae. In: Rock, J.F. (ed.), Palmyra Island with a description of its flora. Bull. Coll. Hawaii Publ. 4: 44-48.

Beccari, O. (1917). Origin and dispersal of Cocos nucifera. Philipp. J. Sci., C12: 27-43.

BlAKey, R.C. (2008). Gondwana paleogeography from assembly to breakup - a 500 m.y. odyssey. In: Fielding, C.R. et al. (ed.), Resolving the Late Paleozoic ice age in time and space. Special Pap. Geol. Soc. Amer. 441: 1-28.

Chiovenda, E. (1921). La culla del cocco. Webbia 5: 199-294.

Chiovenda, E. (1923). La culla del cocco. Webbia 5: 359-449.

Соoк, O.F. (1901). The origin and distribution of the cocoa palm. Contr. U.S. Natl. Herb. 7: 257-298.

Соoк, O.F. (1910). History of the coconut palm in America. Contr. U.S. Natl. Herb. 14: 271-342.

Cuccuini, P. \& C. Nepi (2006). The palms of Odoardo Beccari. Quad. Bot. Amb. Appl. 17.

Dawson, E.Y. (1959). Changes in Palmyra Atoll and its vegetation through the activities of man, 1913-1958. Pacific Naturalist 1(2): $1-51$.

Dransfield, J., N.W. Uhl, C.B. Asmussen, W.J. Baker, M. M. Harley \& C.E. Lewis (2008). Genera Palmarum - the evolution and classification of palms. Royal Botanic Gardens, Kew.

Fosberg, F.R. (1960). A theory on the origin of the coconut. In: Arthur, A.J. (ed.), Symposium on the impact of man on humid tropics vegetation, Goroka, Territory of Papua and New Guinea, September, 1960: 73-75. Commonwealth Government Printers, Canberra. 
Freeman, S. (2006a). Vascular flora of Palmyra Atoll - an update to 1992. U.S. Fish and Wildlife Service Administrative Report. Honolulu.

Freeman, S. (2006b). Plants of Palmyra - an unofficial guide to the vascular flora of Palmyra Atoll. U.S. Fish and Wildlife Service Administrative Report, Honolulu.

Gomez-Navarro, C., C. Jaramillo, F. Herrera, S.L. Wing \& R. Callejas (2009). Palms (Arecaceae) from a Paleocene rainforest of northern Colombia. Amer. J. Bot. 96: 1300-1312.

Harries, H.C. (1978). The evolution, dissemination and classification of Cocos nucifera. Bot. Rev. 44: 265-320.

Harries, H.C. (1979). Nuts to the Garden of Eden. Principes 23: 143-148.

Harries, H.C. (1981). Germination and taxonomy of the coconut palm. Ann. Bot. 48: 873-883.

Harries, H.C. (2012). Germination rate is the significant characteristic determining coconut palm diversity. AoB Plants 2012: pls045. DOI: $10.1093 /$ aobpla/pls045

Harries, H.C. \& C.R. Clements (2014). Long-distance dispersal of the coconut palm by migration within the coral atoll ecosystem. Ann Bot. 113: 565-570.

Harries, H. \& J. Harries (2018). The cradle of the coconut: Emilio Chiovenda's 'La Culla del Cocco' (1921-1923) revisited. Webbia 73: 155-158.

Hathaway, S.A., K. McEachern \& R.N. Fisher (2011). Terrestrial Forest Management Plan for Palmyra Atoll. Open-File Report 2011-1007. The Nature Conservancy Palmyra Program, U.S. Department of the Interior, U.S. Geological Survey.

Herbst, D. (1988). Flora and vegetation of Palmyra Atoll. U.S. Fish and Wildlife Service Administrative Report, Honolulu.

Herbst, D. (1992). Flora and vegetation of Palmyra Atoll. U.S. Fish and Wildlife Service Administrative Report, Honolulu.

Martelli, U. (1916). Pandanaceae. In: Rock, J.F. (ed.), Palmyra Island with a description of its flora. Bull. Coll. Hawaii Publ. 4: 41-43.

Martius, C.F.P. von (1823-1850). Historia naturalis palmarum. Leipzig.

Meerow, A.W., L. Noblick \& J.W. Borrone (2009). Phylogenetic analysis of seven WRKY genes across the palm subtribe Attaleinae (Arecaceae) identifies Syagrus as sister group of the coconut. PLoS ONE 4: e7353. DOI: 10.1371/ journal.pone.0007353

Meerow, A.W., L. Noblick, D.E. Salas-Leiva, V. Sanchez, J. Francisco-Ortega, B. Jestrow \& K. Nakamura (2015). Phylogeny and historical biogeography of the cocosoid palms (Arecaceae, Arecoideae, Cocoseae) inferred from sequences of six WRKY gene family loci. Cladistics 31: 509-534.
MSNFI (2019). Museo di Storia Naturale, Sezione Botanica "Filippo Parlatore". [http://parlatore.msn.unifi.it/types]

Pandanaceae Project (2019). Conservatoire et Jardin botaniques de la Ville de Genève \& Missouri Botanical Garden (coord.). [http://www.tropicos.org/Project/Pandanaceae]

Purseglove, J.W. (1968). Origin and distribution of the coconut. Trop. Sci. 10: 191-199.

Purseglove, J.W. (1972). Tropical crops: monocotyledons. Longman, London.

Rоск, J.F. (1916). Palmyra Island with a description of its flora. Bull. Coll. Hawaii Publ. 4.

Sadler, J.C. (1959). A study of some recent climatological data of the Line Islands. In: Anon., Proceedings of the Ninth Pacific Science Congress of the Pacific Science Association, Department of Science: 12-16. Bangkok.

Sauer, J.D., C.L. Ridley, J.C. Kelly, C.W. Pennington \& R.L. RANDs (1967). A re-evaluation of coconut as an indicator of buman dispersal. Man across the sea. University of Texas Press, Austin.

Shukla, A., R.C. Mehrotra \& J.S. Guleria (2012). Cocos sahnii Kaul: a Cocos nucifera L.-like fruit from the Early Eocene rainforest of Rajasthan, western India. J. Biosci. 37: 769-776.

Streets, T.H. (1877). Some account of the natural history of the Fanning group of islands. American Naturalist 11(2): 6-72.

Walker, T.A. (1991). Pisonia Islands of the Great Barrier Reef, part 1 - the distribution, abundance, and dispersal by sea birds of Pisonia grandis. Atoll. Res. Bull.350: 1-23.

Wegmann, A. (2005). Palmyra Atoll National Wildlife Refuge forest type map. U.S. Fish and Wildlife Service, Honolulu.

Whitehead, R.A. (1965). Speed of germination, a characteristic of possible taxonomic significance in Cocos nucifera L. Trop. Agric. (Trinidad) 42: 369-372.

Young, H.S., D.J. McCauley, R.B. Dunbar \& R. Dirzo (2010). Plants cause ecosystem nutrient depletion via the interruption of bird-derived spatial subsidies. Proc. Nat. Acad. Sci. USA 107: 2072-2077. 